\title{
Scrap NHS fees for overseas healthcare staff, says Labour
}

\section{Abi Rimmer}

The BMJ

The Labour party has called on the government to scrap the NHS surcharge for overseas health professionals and care workers by seeking an amendment to the Immigration Bill. Introduced in 2015, the surcharge means that people from outside the EU must pay $£ 400$ ( $€ 445$; \$488) per person per year to use the NHS. This charge will increase to $£ 624$ per year in October and will apply to EU nationals moving to the UK after the Brexit transition period.

Speaking at Questions to the Prime Minister on 20 May, Labour leader Keir Starmer said, "Every Thursday we go out and clap for our carers. Many of them are risking their lives for the sake of all of us.

"Does the prime minister think it's right that care workers coming from abroad and working on our frontline should have to pay a surcharge of hundreds-sometimes thousands of pounds-to use the NHS themselves?"

Commenting on Labour's call, Chaand Nagpaul described the surcharge as, "unfair, illogical, and penalises hardworking international staff for dedicating their lives to NHS patients."

He added, "Just weeks ago, it was positive to hear the home secretary promising a review of the charge-only for the government to now say nothing will change.

"We continue to urge the government to scrap the charge for healthcare workers and welcome the Labour leader's proposed amendment to the Immigration Bill."
In a letter sent on 18 May, the Doctors' Association UK, the British Association of Physicians of Indian Origin, and the Association of Pakistani Physicians of Northern Europe criticised the home secretary's decision not to review the surcharge.

The letter to Priti Patel said, "At a time when we are mourning colleagues, your steadfast refusal to reconsider the deeply unfair immigration health surcharge is a gross insult to all who are serving this country at its time of greatest need.

"Not only is this a betrayal of all these hardworking people, but also represents a deterrent to attracting talented and skilled workers to the UK-a stated aim of this government's immigration policy."

A government spokesperson said, "To bring peace of mind and to recognise the contribution of frontline NHS and other eligible health workers during this pandemic, we announced free and automatic visa extensions for them, including an exemption from the immigration health surcharge.

"NHS trusts and other employers also offer schemes to support NHS staff in making the payment-in many cases covering the cost of the surcharge themselves. In the longer term it is right that we ensure a contribution is made to reflect the cost of providing NHS treatment and the surcharge has raised $£ 900 \mathrm{~m}$ for the NHS." 